\title{
HUBUNGAN ASUPAN SERAT DENGAN STATUS GIZI DAN PROFIL LIPID DARAH PADA ORANG DEWASA DISLIPIDEMIA
}

\author{
(Association between Fiber Intake with Nutritional Status and Blood Lipid Profile \\ in Dyslipidemic Adults)
}

Lilik Kustiyah" ${ }^{*}$, Maya Utami Widhianti1 ${ }^{1}$, dan Mira Dewi ${ }^{1}$

'Departemen Gizi Masyarakat, Fakultas Ekologi Manusia (FEMA), Institut Pertanian Bogor, Bogor 16680

\begin{abstract}
The objective of this study was to analyze the association of fiber consumption with nutritional status and blood lipid profile in dyslipidemic adults. The design study was cross sectional survey involving 79 subjects. The results showed that there were significant correlations between energy intake with High Density Lipoprotein (HDL) cholesterol and total cholesterol, fat intake with BMI (Body Mass Index), and BMI with Low Density Lipoprotein (LDL) cholesterol and total cholesterol $(p<0.05)$. There was no significant correlation between consumption of fiber with nutritional status and blood lipid profile $(p>0.05)$. In conclusion, most of the dyslipidemia subjects were obese. Dyslipidemia subjects should keep their intake of energy and fat in recommended ranges in order not to be obese and keep the BMI in normal range to avoid abnormalities of blood lipid profile.
\end{abstract}

Keywords: blood lipid profile, dyslipidemia, fiber intake, nutritional status

\begin{abstract}
ABSTRAK
Penelitian ini bertujuan untuk menganalisis hubungan asupan serat dengan status gizi dan profil lipid darah pada orang dewasa dislipidemia. Desain penelitian ini adalah survei potong lintang dengan subjek penelitian sebanyak 79 subjek. Hasil penelitian menunjukkan bahwa terdapat hubungan yang signifikan antara asupan energi dengan kolesterol High Density Lipoprotein (HDL) dan kolesterol total, asupan lemak dengan IMT (Indeks Massa Tubuh), dan IMT dengan kolesterol Low Density Lipoprotein (LDL) dan kolesterol total ( $<0.05)$. Tidak terdapat hubungan yang signifikan antara asupan serat dengan status gizi dan profil lipid darah ( $p>0.05$ ). Disimpulkan bahwa sebagian besar subjek yang obes mengalami dislipidemia. Subjek penderita dislipidemia sebaiknya menjaga asupan energi dan lemak agar tidak mengalami kegemukan dan menjaga batas IMT normal untuk menghindari abnormalitas pada profil lipid darah.
\end{abstract}

Kata kunci: asupan serat, dislipidemia, profil lipid darah, status gizi

"Korespondensi: Departemen Gizi Masyarakat, Fakultas Ekologi Manusia (FEMA), Institut Pertanian Bogor, Bogor 16680. Email: lilikku@ipb.ac.id 


\section{PENDAHULUAN}

Salah satu pemicu penyakit degeneratif adalah dislipidemia. Dislipidemia merupakan suatu kondisi ketidaknormalan profil lipid yang mencakup kadar trigliserida (TGA), kolesterol total, kolesterol low density lipoprotein (LDL), dan kolesterol high density lipoprotein (HDL) (Osuji et al. 2010). Dislipidemia merupakan faktor utama terjadinya penyakit jantung koroner (Anwar 2004).

Obesitas merupakan faktor yang memengaruhi terjadinya dislipidemia (Setiono 2012). Masalah kelebihan atau kekurangan gizi yang terjadi pada usia dewasa akan memengaruhi produktivitas kerjanya (Badriah 2011). Suatu bahan pangan yang direkomendasikan dalam mengontrol kadar lipid darah dan status gizi adalah serat. Serat merupakan suatu bahan pangan yang tidak dapat dicerna oleh enzim-enzim pencernaan. Terdapat dua macam serat, yaitu serat larut dan serat tidak larut (Kusharto 2006). Orang yang obes cenderung mengalami dislipidemia (Janssen et al. 2004). Orang yang mengalami dislipidemia sangat dianjurkan untuk mengonsumsi serat mengingat peranan serat dalam penurunan kadar kolesterol darah dan pengaruhnya terhadap status gizi.

Penelitian ini dilakukan untuk mengkaji hubungan asupan serat dengan status gizi dan profil lipid darah pada orang dewasa dislipidemia. Tujuan umum dalam penelitian ini adalah mengkaji hubungan asupan serat dengan status gizi dan profil lipid darah pada orang dewasa dislipidemia.

\section{METODE}

\section{Desain, Tempat, dan Waktu Penelitian}

Penelitian ini menggunakan sebagian data dari penelitian yang berjudul "Studi Efikasi Intervensi Minyak Goreng yang diperkaya Plant-Sterol untuk Memperbaiki Profil Lipid dan Status Inflamasi pada Individu Hiperlipidemia". Desain penelitian adalah cross-sectional. Penentuan lokasi dilakukan secara purposive dengan pertimbangan kemudahan akses, yaitu di Kota dan Kabupaten Bogor. Penelitian dilaksanakan pada bulan Juli-September 2012.

\section{Jumlah dan Cara Penarikan Subjek}

Subjek pada penelitian ini menggunakan subjek yang telah terpilih dari penelitian payung dan dilakukan secara purposive. Kriteria inklusi penarikan subjek adalah dislipidemia (subjek dengan kadar kolesterol $\mathrm{HDL}<40.0 \mathrm{mg} / \mathrm{dL}$ atau kolesterol LDL $\geq 130.0 \mathrm{mg} / \mathrm{dL}$ atau trigliserida $\geq 150.0 \mathrm{mg} / \mathrm{dL}$ atau kolesterol total $\geq 200.0 \mathrm{mg} / \mathrm{dL}$ ). Pengukuran kadar kolesterol HDL, kolesterol LDL, trigliserida, dan kolesterol total telah dilakukan pada saat screening di penelitian payung. Subjek yang terpilih dalam penelitian ini berjumlah 79 subjek.

\section{Jenis dan Cara Pengumpulan Data}

Data yang digunakan mencakup data primer dan data sekunder. Data primer berupa asupan serat (recall 1x24 jam). Data sekunder yang diperoleh dari penelitian payung, meliputi 1) karakteristik subjek (usia, jenis kelamin); 2) konsumsi pangan (recall 1x24 jam); 3) profil lipid darah (kolesterol HDL, kolesterol LDL, kolesterol total, dan trigliserida); dan 4) berat badan (BB) dan tinggi badan (TB), Lingkar Pinggang (LP), Rasio Lingkar Pinggang Panggul (RLPP), dan persentase lemak tubuh). Data karakteristik subjek dikumpulkan dengan cara wawancara menggunakan kuesioner; data konsumsi pangan dikumpulkan dengan metode recall 1×24 jam; data profil lipid darah diperoleh melalui analisis laboratorium; data BB,TB, dan LP diperoleh dengan cara pengukuran langsung.

Darah diambil dari pembuluh darah vena pada lipatan siku lengan sebanyak $5.0 \mathrm{~mL}$. Pengambilan darah dilakukan pada pagi hari sekitar pukul 07.0008.00 WIB pada subjek yang telah puasa minimal delapan jam sebelumnya. Batas maksimal pengambilan darah hingga analisis serum darah adalah dua jam. Profil lipid darah dianalisis menggunakan metode spektrofotometri. Analisis profil lipid darah dilakukan oleh laboratorium kesehatan Prodia ${ }^{\circ}$ Kota Bogor.

\section{Pengolahan dan Analisa Data}

Data asupan serat dikategorikan berdasarkan anjuran asupan serat (Hardinsyah \& Tambunan 2004 dalam Kusharto 2006) yaitu 19.0-30.0 g/hari dengan kategori kurang (<19.0 g/hari), cukup (19.0$30.0 \mathrm{~g} /$ hari), dan lebih (>30.0 g/hari). Kecukupan lemak total ditentukan berdasarkan asupan lemak total berkisar antara 20-30\% asupan energi (WNPG 2004). Tingkat kecukupan lemak dikategorikan menjadi kurang $(<20 \%$ asupan energi), cukup (20-30\% asupan energi) dan lebih ( $>30 \%$ asupan energi). Data konsumsi pangan dikonversi ke dalam asupan energi (kkal) dan lemak (gram) berdasarkan DKBM (Daftar Komposisi Bahan Makanan), serta serat (gram) menggunakan DBMP (Daftar Bahan Makanan Penukar).

Analisis deskriptif digunakan untuk menggambarkan karakteristik subjek, konsumsi pangan (asupan energi, lemak, dan serat), status gizi (IMT, lingkar pinggang/LP, rasio lingkar pinggang panggul/ RLPP, persentase lemak tubuh/LT), dan profil lipid darah (kolesterol HDL, kolesterol LDL, kolesterol total, dan trigliserida). Berdasarkan WHO (2008), LP laki-laki dikategorikan normal jika $<85 \mathrm{~cm}$ dan berisiko komplikasi metabolik jika $\geq 85 \mathrm{~cm}$, untuk perempuan dikategorikan normal jika $<80 \mathrm{~cm}$ dan berisiko komplikasi metabolik jika $\geq 80 \mathrm{~cm}$. Berdasarkan Lee \& Nieman (2010), RLPP laki-laki dikategorikan normal jika $<0.9$ dan berisiko komplikasi metabolik jika $\geq 0.9$, untuk perempuan dikategorikan normal jika $<0.8$ dan berisiko komplikasi metabolik 
jika $\geq 0.8$. Persentase LT untuk laki-laki dikategorikan normal jika $<25 \%$ dan tinggi jika $\geq 25 \%$, untuk perempuan dikategorikan normal jika $<32 \%$ dan tinggi jika $\geq 32 \%$. Analisis inferensia digunakan untuk melihat hubungan (korelasi) antar variabel.

\section{HASIL DAN PEMBAHASAN}

\section{Konsumsi Pangan Subjek}

Kisaran asupan energi subjek setelah di cleaning adalah 158-3 $013 \mathrm{kkal} / \mathrm{hari}$ dengan rata-rata asupan energi sebesar $1261 \pm 596 \mathrm{kkal} / \mathrm{hari}$. Pada umumnya subjek memiliki tingkat kecukupan energi yang tergolong defisit berat (59.5\%). Subjek yang termasuk dalam kategori tingkat kecukupan energi defisit sedang dan ringan masing-masing sebesar 8.9\% dan 7.6\%, tingkat kecukupan energi normal sebesar $17.7 \%$, dan hanya $6.3 \%$ subjek termasuk dalam kategori tingkat kecukupan energi lebih.

Asupan lemak subjek setelah di cleaning berkisar antara 2.0-244.0 g/hari. Rata-rata asupan lemak subjek adalah $42.7 \pm 41.9 \mathrm{~g} /$ hari. Seluruh subjek termasuk dalam kategori tingkat kecukupan lemak kurang (100.0\%). Asupan serat subjek berkisar antara $0.4-57.5 \mathrm{~g} /$ hari. Rata-rata asupan serat subjek adalah $15.5 \pm 13.0 \mathrm{~g} /$ hari. Pada umumnya asupan serat subjek masih tergolong rendah. Sebanyak $68.4 \%$ subjek tergolong dalam kategori kurang sedangkan $20.3 \%$ subjek tergolong cukup, dan $11.4 \%$ subjek tergolong lebih.

\section{Status Gizi Subjek}

Indeks massa tubuh subjek berkisar antara

$18.8-41.6 \mathrm{~kg} / \mathrm{m}^{2}$ dengan rata-rata sebesar $27.9 \pm 4.9$ $\mathrm{kg} / \mathrm{m}^{2}$. Sebanyak $38.0 \%$ dan $32 \%$ subjek masing-masing tergolong dalam kategori obes I dan obes II. Subjek yang gemuk (obes I dan II) terdiri dari $26 \%$ laki-laki dan $74 \%$ perempuan. Obesitas terjadi karena ketidakseimbangan energi antara intake energi dan energi yang digunakan (Elliot et al. 2011). Lingkar pinggang dapat digunakan sebagai indikator pengukuran distribusi lemak tubuh dan obesitas sentral (Romaguera et al. 2011).

Kisaran LP subjek laki-laki adalah 71.0-115.0 $\mathrm{cm}$ dengan rata-rata sebesar $92.3 \pm 11.5 \mathrm{~cm}$. LP subjek perempuan berkisar antara $70.0-116.0 \mathrm{~cm}$ dengan rata-rata sebesar $95 \pm 9.8 \mathrm{~cm}$. Rata-rata LP pada subjek secara total adalah $94.0 \pm 10.0 \mathrm{~cm}$. Pada umumnya baik subjek laki-laki (21.5\%) maupun perempuan (69.6\%) tergolong dalam kategori berisiko mengalami komplikasi metabolik. Rata-rata LP perempuan $(95.1 \pm 9.8 \mathrm{~cm})$ lebih besar dibandingkan dengan laki-laki $(92.3 \pm 9.9 \mathrm{~cm})$. Hasil studi Maruf et al. (2012) di Nigeria menunjukkan bahwa perempuan umumnya memiliki lingkar pinggang lebih besar daripada laki-laki. Nilai lingkar pinggang yang tinggi berkorelasi positif dengan peningkatan terjadinya dislipidemia (Al-Ajlan 2011).
Kisaran RLPP subjek laki-laki adalah 0.5-1.0 sedangkan pada subjek perempuan adalah 0.8-1.1. Rata-rata RLPP pada kedua subjek adalah $0.9 \pm 0.1$ dengan rata-rata LP pada subjek secara total adalah $0.9 \pm 0.1$. Subjek laki-laki $(24.1 \%)$ dan perempuan (70.9\%) tergolong dalam kategori berisiko mengalami komplikasi metabolik. Pengukuran persentase lemak tubuh digunakan untuk membedakan antara massa lemak tubuh dan massa bukan lemak tubuh. Kisaran persentase lemak tubuh subjek laki-laki adalah $17.5-37.6 \%$ sedangkan pada subjek perempuan adalah $24.7-44.9 \%$. Rata-rata persentase pada subjek laki-laki adalah $28 \pm 4.8 \%$ sedangkan subjek perempuan adalah $35.39 \pm 5.5 \%$. Subjek laki-laki (24.1\%) dan perempuan (55.7\%) tergolong dalam kategori tinggi.

\section{Profil Lipid Darah Subjek}

Rata-rata kadar profil lipid darah subjek disajikan pada Tabel 1. Kadar kolesterol HDL subjek berkisar antara $29.0-68.0 \mathrm{mg} / \mathrm{dL}$. Rata-rata kadar kolesterol HDL seluruh subjek sebesar $46.2 \pm 9.2 \mathrm{mg} /$ dL. Sebagian besar subjek (60.8\%) tergolong dalam kategori normal $(>40 \mathrm{mg} / \mathrm{dL}$ ). Pada umumnya kadar kolesterol HDL subjek perempuan $(48.8 \pm 8.5 \mathrm{mg} / \mathrm{dL})$ cenderung lebih tinggi dibandingkan subjek laki-laki $(37.5 \pm 5.8 \mathrm{mg} / \mathrm{dL})$.

Tabel 1. Rata-rata Kadar Kolesterol HDL, Kolesterol LDL, Kolesterol Total, dan Trigliserida pada Subjek

\begin{tabular}{lcc}
\hline $\begin{array}{c}\text { Fraksi Lipid Darah } \\
(\mathrm{mg} / \mathrm{dL})\end{array}$ & $\begin{array}{c}\text { Rata-rata } \\
(\mathrm{mg} / \mathrm{dL})\end{array}$ & $\begin{array}{c}\text { Normal } \\
(\mathrm{mg} / \mathrm{dL})^{*}\end{array}$ \\
\hline Kolesterol HDL & $46.2 \pm 9.2$ & $40-60$ \\
Kolesterol LDL & $146.3 \pm 29.3$ & $<100$ \\
Kolesterol Total & $220.6 \pm 29.8$ & $<200$ \\
Trigliserida & $164.0 \pm 84.0$ & $<150$ \\
\hline
\end{tabular}

"Sumber: Lee \& Nieman (2010)

Tingginya kadar LDL dalam darah dapat menyebabkan terjadinya penyakit jantung koroner. Kisaran kadar kolesterol LDL subjek adalah 61.0$213.0 \mathrm{mg} / \mathrm{dL}$ dengan rata-rata sebesar $146.3 \pm 29.3$ $\mathrm{mg} / \mathrm{dL}$. Sebanyak $39.2 \%$ subjek tergolong dalam kategori borderline high (150.0-169.0 mg/dL). Pada umumnya subjek perempuan cenderung memiliki kadar kolesterol LDL yang lebih tinggi dibandingkan subjek laki-laki.

Hubungan antara Asupan Serat dengan Status Gizi Uji korelasi Pearson menunjukkan bahwa tidak terdapat hubungan yang signifikan antara asupan serat dengan IMT, LP, RLPP, dan persentase lemak tubuh ( $p>0.05)$. Diduga karena asupan serat subjek masih tergolong rendah (<19.0 g/hari) sehingga belum berhubungan signifikan dengan status gizi.

Tidak terdapatnya korelasi signifikan antara IMT dengan asupan serat sejalan dengan penelitian 
Cheng et al. (2009) di Jerman dan Newby et al. (2003) di Dakota Utara. Akan tetapi hasil penelitian ini tidak sesuai dengan penelitian yang dilakukan oleh Duvigneaud et al. (2007) di Flemish menunjukkan bahwa terdapat hubungan negatif signifikan antara asupan serat dengan IMT. Hal ini karena jumlah subjek yang diteliti lebih besar yaitu 847 orang dan pengambilan data konsumsi dilakukan selama tiga hari. Studi Davis et al. (2009) di Amerika Serikat menunjukkan bahwa penurunan asupan serat akan menaikkan jaringan adiposa viseral. Kelebihan energi dapat dicegah dengan mengonsumsi sayur dan buah (Newby et al. 2003).

Berdasarkan studi Hu et al. (2010) di Eropa bahwa serat dapat mencegah terjadinya peningkatan berat badan dan lingkar pinggang. Penelitian Van De Vijver et al. (2009) di Belanda dan Liu et al. (2003) di Amerika Serikat menunjukkan bahwa IMT semakin meningkat seiring dengan menurunnya asupan biji-bijian. Overweight atau obesitas disebabkan oleh adanya perubahan pola asupan makan yang rendah sayur, buah, kacang-kacangan sedangkan tinggi dalam mengonsumsi daging, lemak, susu, dan hasil olahannya (Al-Ajlan 2011).

Sebagian besar subjek dengan status gizi berlebih dalam penelitian ini cenderung memiliki asupan serat yang lebih rendah dibandingkan dengan yang status gizi normal. Status gizi subjek termasuk dalam kategori obes baik berdasarkan IMT, LP, RLPP, dan persentase lemak tubuh. Menurut studi Duvigneaud et al. (2007) di Flemish bahwa asupan serat orang obes lebih rendah dibandingkan orang normal. Sebaran asupan serat subjek menurut status gizi ditampilkan pada Tabel 2 .

Berdasarkan Tabel 2 dapat dilihat bahwa meskipun tidak terdapat hubungan yang signifikan akan tetapi pada umumnya pada subjek yang status gizi normal cenderung mengonsumsi serat lebih tinggi daripada subjek yang status gizi berlebih. Berdasarkan hasil uji independent sample t-test asupan serat antara subjek dengan status gizi normal dengan status gizi berlebih menunjukkan bahwa tidak terdapat perbedaan yang signifikan $(p>0.05)$.

\section{Hubungan antara Asupan Serat dengan Profil Lipid Darah}

Uji korelasi Pearson menunjukkan bahwa tidak terdapat hubungan yang signifikan antara asupan serat dengan kolesterol HDL, kolesterol LDL, kolesterol total, dan trigliserida $(p>0.05)$. Diduga karena asupan serat subjek masih tergolong rendah (<19.0 g/hari) sehingga belum berhubungan signifikan dengan profil lipid darah. Serat memiliki efek dapat menurunkan kadar kolesterol LDL dan koles-

Tabel 2. Sebaran Asupan Serat Subjek berdasarkan Status Gizi

\begin{tabular}{|c|c|c|c|c|c|c|c|c|}
\hline \multirow{3}{*}{ Status Gizi } & \multicolumn{6}{|c|}{ Asupan Serat } & \multirow{2}{*}{\multicolumn{2}{|c|}{ Total }} \\
\hline & \multicolumn{2}{|c|}{ Kurang } & \multicolumn{2}{|c|}{ Cukup } & \multicolumn{2}{|c|}{ Lebih } & & \\
\hline & $\mathrm{n}$ & $\%$ & $\mathrm{n}$ & $\%$ & $\mathrm{n}$ & $\%$ & $\mathrm{n}$ & $\%$ \\
\hline \multicolumn{9}{|l|}{ IMT: } \\
\hline Kurus & 0 & 0.0 & 0 & 0.0 & 0 & 0.0 & 0 & 0.0 \\
\hline Normal & 9 & 17.0 & 3 & 19.0 & 1 & 11.0 & 13 & 16.0 \\
\hline Overweight & 10 & 19.0 & 0 & 0.0 & 1 & 11.0 & 11 & 14.0 \\
\hline Obes 1 & 18 & 33.0 & 10 & 63.0 & 2 & 22.0 & 30 & 38.0 \\
\hline Obes 2 & 17 & 31.0 & 3 & 19.0 & 5 & 56.0 & 25 & 32.0 \\
\hline \multicolumn{9}{|l|}{ Lingkar Pinggang: } \\
\hline Berisiko (laki-laki) & 10 & 19.0 & 4 & 25.0 & 3 & 33.0 & 17 & 22.0 \\
\hline Berisiko (perempuan) & 38 & 70.0 & 11 & 69.0 & 6 & 67.0 & 55 & 70.0 \\
\hline Normal (laki-laki) & 4 & 7.0 & 0 & 0.0 & 0 & 0.0 & 4 & 5.0 \\
\hline Normal (perempuan) & 2 & 4.0 & 1 & 6.0 & 0 & 0.0 & 3 & 4.0 \\
\hline \multicolumn{9}{|c|}{ Rasio Lingkar Pinggang Panggul: } \\
\hline Normal (laki-laki) & 1 & 2.0 & 0 & 0.0 & 1 & 11.0 & 2 & 3.0 \\
\hline Normal (perempuan) & 1 & 2.0 & 1 & 6.0 & 0 & 0.0 & 2 & 3.0 \\
\hline Berisiko (laki-laki) & 13 & 24.0 & 4 & 25.0 & 2 & 22.0 & 19 & 24.0 \\
\hline Berisiko (perempuan) & 39 & 72.0 & 11 & 69.0 & 6 & 67.0 & 56 & 71.0 \\
\hline \multicolumn{9}{|l|}{ Persentase Lemak Tubuh: } \\
\hline Tinggi (laki-laki) & 12 & 22.0 & 4 & 25.0 & 3 & 33.0 & 19 & 24.0 \\
\hline Tinggi (perempuan) & 29 & 54.0 & 9 & 56.0 & 6 & 67.0 & 44 & 56.0 \\
\hline Normal (laki-laki) & 2 & 4.0 & 0 & 0.0 & 0 & 0.0 & 2 & 3.0 \\
\hline Normal (perempuan) & 11 & 20.0 & 3 & 19.0 & 0 & 0.0 & 14 & 18.0 \\
\hline
\end{tabular}


terol total. Hasil penelitian ini berbeda dengan penelitian Suwimol et al. (2012) pada subjek berusia 18-30 tahun di Bangkok yang menunjukkan bahwa asupan serat berkorelasi positif dengan kadar kolesterol LDL. Hal ini karena asupan serat pada subjek penelitiannya lebih tinggi yaitu sebesar 5.0-8.0 porsi/hari atau setara kira-kira dengan $400.0 \mathrm{~g} /$ hari sedangkan rata-rata asupan serat subjek dalam penelitian ini sebesar $15.5 \mathrm{~g} /$ hari.

Sebagian besar subjek yang memiliki ketidaknormalan profil lipid darah dalam penelitian ini cenderung memiliki asupan serat yang lebih rendah dibandingkan dengan yang normal. Sebaran asupan serat subjek menurut profil lipid darah ditampilkan pada Tabel 3.

Berdasarkan Tabel 3 dapat dilihat bahwa meskipun tidak terdapat hubungan yang signifikan akan tetapi pada umumnya pada subjek yang memiliki kadar HDL normal cenderung memiliki asupan serat yang lebih tinggi dibanding dengan subjek yang memiliki kadar HDL rendah. Subjek yang memiliki kadar kolesterol LDL dan kolesterol total tinggi cenderung memiliki asupan serat yang lebih rendah dibandingkan dengan yang normal. Sementara itu, subjek yang memiliki kadar trigliserida rendah cenderung memiliki asupan serat yang lebih tinggi dibandingkan dengan subjek yang memiliki kadar trigliserida tinggi. Berdasarkan hasil uji independent sample t-test asupan serat antara subjek profil lipid darah normal dan tidak normal menunjukkan bahwa tidak terdapat perbedaan yang signifikan ( $p>0.05)$.

\section{Hubungan antara Asupan Energi dan Lemak dengan Status Gizi \\ Uji korelasi Pearson menunjukkan bahwa tidak} terdapat hubungan yang signifikan antara asupan energi dengan IMT, LP, RLPP, dan persentase lemak tubuh $(p>0.05)$. Diduga karena asupan energi subjek masih tergolong rendah (rata-rata asupan energi sebesar $1261 \mathrm{kkal} / \mathrm{hari}$ ) sehingga belum berhubungan signifikan dengan status gizi. Penelitian ini sejalan dengan studi Halkjær et al. (2006) di Denmark yang menyatakan bahwa tidak terdapat hubungan yang signifikan antara asupan energi dengan lingkar pinggang. Penelitian yang dilakukan oleh Ledikwe et al. (2006) di Amerika Serikat dan Elliot et al. (2011) di Queensland menunjukkan bahwa asupan energi pada orang obes lebih besar dibandingkan orang yang status gizi normal.

Uji korelasi Spearman menunjukkan bahwa tidak terdapat hubungan yang signifikan antara asupan lemak dengan LP, RLPP, dan persentase lemak tubuh $(p>0.05)$. Diduga karena asupan lemak subjek masih tergolong rendah (rata-rata asupan lemak sebesar $42.7 \pm 41.9 \mathrm{~g} /$ hari) sehingga belum berhubungan signifikan dengan status gizi. Sementara itu terdapat hubungan positif signifikan antara asupan lemak dengan IMT $(\mathrm{p}=0.032 ; \mathrm{r}=0.242)$. Hal

Tabel 3. Sebaran Asupan Serat Subjek berdasarkan Profil Lipid Darah

\begin{tabular}{|c|c|c|c|c|c|c|c|c|}
\hline \multirow{3}{*}{ Fraksi Lipid Darah } & \multicolumn{6}{|c|}{ Asupan Serat } & \multirow{2}{*}{\multicolumn{2}{|c|}{ Total }} \\
\hline & \multicolumn{2}{|c|}{ Kurang } & \multicolumn{2}{|c|}{ Cukup } & \multicolumn{2}{|c|}{ Lebih } & & \\
\hline & $\mathrm{n}$ & $\%$ & $\mathrm{n}$ & $\%$ & $\mathrm{n}$ & $\%$ & $\mathrm{n}$ & $\%$ \\
\hline \multicolumn{9}{|l|}{ HDL: } \\
\hline Normal & 33 & 61.0 & 11 & 69.0 & 4 & 44.0 & 48 & 61.0 \\
\hline Low & 13 & 24.0 & 4 & 25.0 & 5 & 56.0 & 22 & 28.0 \\
\hline High & 8 & 15.0 & 1 & 6.0 & 0 & 0.0 & 9 & 11.0 \\
\hline \multicolumn{9}{|l|}{ LDL: } \\
\hline Optimal & 2 & 4.0 & 2 & 13.0 & 0 & 0.0 & 4 & 5.0 \\
\hline Near optimal & 10 & 19.0 & 3 & 19.0 & 5 & 56.0 & 18 & 23.0 \\
\hline Borderline high & 22 & 41.0 & 7 & 44.0 & 2 & 22.0 & 31 & 39.0 \\
\hline High & 15 & 28.0 & 2 & 13.0 & 2 & 22.0 & 19 & 24.0 \\
\hline Very high & 5 & 9.0 & 2 & 13.0 & 0 & 0.0 & 7 & 9.0 \\
\hline \multicolumn{9}{|l|}{ Trigliserida: } \\
\hline Normal & 32 & 59.0 & 7 & 44.0 & 4 & 44.0 & 43 & 54.0 \\
\hline Borderline high & 13 & 24.0 & 2 & 13.0 & 3 & 33.0 & 18 & 23.0 \\
\hline High & 9 & 17.0 & 7 & 44.0 & 2 & 22.0 & 18 & 23.0 \\
\hline Very high & 0 & 0.0 & 0 & 0.0 & 0 & 0.0 & 0 & 0.0 \\
\hline \multicolumn{9}{|l|}{ Kolesterol total: } \\
\hline Desirable & 12 & 22.0 & 7 & 44.0 & 1 & 11.0 & 20 & 25.0 \\
\hline Borderline high & 24 & 44.0 & 5 & 31.0 & 8 & 89.0 & 37 & 47.0 \\
\hline High & 18 & 33.0 & 4 & 25.0 & 0 & 0.0 & 22 & 28.0 \\
\hline
\end{tabular}


ini berarti semakin tinggi asupan lemak subjek maka semakin tinggi nilai IMT-nya. Sebagian besar subjek termasuk dalam kategori obes I. Diet tinggi lemak merupakan penyebab utama terjadinya obesitas (Singh et al. 2011).

\section{Hubungan antara Asupan Energi dan Lemak dengan Profil Lipid Darah}

Uji korelasi Pearson menunjukkan bahwa tidak terdapat hubungan yang signifikan antara asupan energi dengan kolesterol LDL dan trigliserida ( $p>0.05)$. Diduga karena asupan energi subjek masih tergolong rendah (rata-rata asupan energi sebesar 1261 kkal/ hari) sehingga belum berhubungan signifikan. Terdapat hubungan negatif signifikan antara asupan energi dengan kolesterol HDL $(p=0.026 ; r=-0.250)$ dan kolesterol total $(p=0.005 ; r=-0.314)$. Studi Merchant et al. (2007) di Eropa, Cina, Asia Selatan, dan Kanada, serta studi Al-Ajlan (2011) di Riyadh menunjukkan bahwa semakin rendah asupan energi maka semakin tinggi kadar kolesterol HDL. Terdapat hubungan negatif signifikan antara kolesterol total dengan energi. Semakin tinggi asupan energi maka kadar kolesterol darah semakin rendah. Hal ini diduga karena pengambilan data konsumsi dilakukan dalam waktu satu hari. Sementara itu, kadar koleterol di dalam darah terbentuk dalam waktu yang lama.

Uji korelasi Spearman menunjukkan bahwa tidak terdapat hubungan yang signifikan antara asupan lemak dengan kolesterol HDL, kolesterol LDL, kolesterol total, dan trigliserida $(p>0.05)$. Diduga karena asupan lemak subjek masih tergolong rendah (rata-rata asupan lemak sebesar $42.7 \pm 41.9 \mathrm{~g} /$ hari) sehingga belum berhubungan signifikan dengan profil lipid darah. Rata-rata asupan lemak subjek masih tergolong baik karena masih berada dalam kisaran 15-30\% dari rata-rata total energi subjek. Lemak jenuh akan merangsang hati untuk memproduksi kolesterol LDL dalam jumlah besar dan meningkatkan kolesterol darah (Sartika 2011).

Beberapa faktor yang diduga memengaruhi rendahnya asupan energi dan lemak pada subjek penelitian adalah adanya flat slope syndrome ketika pengambilan data recall (Supariasa et al. 2001). Subjek yang obes cenderung akan mengatakan bah- wa makanan yang diasupnya lebih sedikit daripada biasanya sedangkan subjek yang kurus cenderung mengatakan sebaliknya. Selain itu, kemungkinan ketika dilakukan recall, subjek lupa jenis dan jumlah makanan yang diasup pada hari sebelumnya. Kemungkinan lainnya adalah subjek yang obes telah sadar bahwa ia harus mengubah pola konsumsinya agar menurunkan berat badannya sehingga ketika dilakukan pengambilan data, asupan energi dan lemak subjek cenderung lebih rendah karena sudah melakukan pengurangan konsumsi makanan. Sebaran jenis makanan yang dikonsumsi subjek berdasarkan status gizi disajikan pada Tabel 4. Berdasarkan Tabel 4 dapat dilihat bahwa subjek obes cenderung lebih tinggi dalam mengonsumsi gorengan (90.0\%), kue, roti, dan biskuit (72.0\%) dibandingkan dengan subjek normal.

\section{Hubungan antara Status Gizi dengan Profil Lipid Darah}

Uji korelasi Pearson menunjukkan bahwa terdapat hubungan yang signifikan antara status gizi (nilai IMT) dengan kolesterol LDL $(p=0.004 ; r=0.320)$ dan kolesterol total $(p=0.010 ; r=0.289)$. Hal ini berarti semakin besar nilai IMT, maka semakin tinggi kadar LDL dan kolesterol total. Akan tetapi tidak terdapat hubungan yang signifikan antara IMT dengan kolesterol HDL dan trigliserida $(p>0.05)$. Studi Al-Ajlan (2011) di Riyadh menunjukkan bahwa IMT berkorelasi positif dengan LDL dan kolesterol total sedangkan berkorelasi negatif dengan kolesterol HDL tetapi tidak berkorelasi dengan kadar trigliserida. Adanya perbedaan hasil karena subjek yang ditelitinya (18-35 tahun) berjumlah lebih besar yaitu 333 subjek. Studi Schröder et al. (2003) di Spanyol menunjukkan bahwa IMT berkorelasi positif dengan kolesterol total dan kolesterol LDL.

Terdapatnya korelasi antara status gizi dengan kolesterol LDL dan kolesterol total sejalan dengan hasil penelitian Ighosotu et al (2010) di Nigeria bahwa subjek dengan status gizi berlebih memiliki profil lipid darah terutama kolesterol yang lebih tinggi. Kadar kolesterol meningkat seiring meningkatnya berat badan.

Tabel 4. Sebaran Konsumsi Makanan Subjek berdasarkan Status Gizi

\begin{tabular}{lcccccc}
\hline \multirow{2}{*}{ Jenis Makanan yang Dikonsumsi } & \multicolumn{2}{c}{ Status Gizi Normal } & \multicolumn{2}{c}{ Status Gizi Lebih } & \multicolumn{2}{c}{ Total } \\
\cline { 2 - 7 } & $\mathrm{n}$ & $\%$ & $\mathrm{n}$ & $\%$ & $\mathrm{n}$ & $\%$ \\
\hline Makanan pokok & 13 & 16.0 & 66 & 84.0 & 79 & 100.0 \\
Lauk hewani & 3 & 33.0 & 6 & 67.0 & 9 & 100.0 \\
Lauk nabati & 6 & 14.0 & 36 & 86.0 & 42 & 100.0 \\
Gorengan & 2 & 10.0 & 18 & 90.0 & 20 & 100.0 \\
Sayur & 9 & 19.0 & 39 & 81.0 & 48 & 100.0 \\
Buah & 7 & 27.0 & 19 & 73.0 & 26 & 100.0 \\
Kue, roti, biskuit & 7 & 28.0 & 18 & 72.0 & 25 & 100.0 \\
\hline
\end{tabular}




\section{KESIMPULAN}

Sebagian besar subjek dislipidemia cenderung memiliki status gizi lebih (berdasarkan IMT, LP, RLPP, dan persentase lemak tubuh). Berdasarkan hasil uji korelasi Pearson dan Spearman dapat diketahui bahwa tidak terdapat hubungan yang signifikan antara asupan serat dengan status gizi dan profil lipid darah, antara asupan energi dengan status gizi subjek, dan antara asupan lemak dengan profil lipid darah $(p>0.05)$. Akan tetapi terdapat hubungan negatif signifikan antara asupan energi dengan kolesterol HDL dan kolesterol total, terdapat hubungan positif signifikan antara asupan lemak dengan IMT, terdapat hubungan positif signifikan antara IMT dengan kolesterol LDL dan kolesterol total $(p<0.05)$.

Sebagian besar subjek yang obesitas mengalami dislipidemia. Pada subjek penderita dislipidemia, asupan serat tidak berhubungan terhadap status gizi dan profil lipid darah. Subjek penderita dislipidemia sebaiknya menjaga asupan energi dan lemak agar tidak mengalami kegemukan dan menjaga batas IMT normal untuk menghindari abnormalitas pada profil lipid darah.

\section{DAFTAR PUSTAKA}

Al-Ajlan AR. 2011. Lipid profile in relation to anthropometric measurements among college male students in Riyadh, Saudi arabia: cross sectional study. International Journal Biomed Science, 7(2), 112-117.

Anwar BT. 2004. Dislipidemia sebagai faktor risiko jantung koroner. http://repositoryusu.ac.id [diakses 5 Maret 2013].

Badriah DL. 2011. Gizi dalam Kesehatan Reproduksi. Refika, Bandung.

Cheng G, Karaolis-Danckert N, Libuda L, Bolzenius K, Remer T, \& Buyken AE. 2009. Relation of dietary glycemic index, glycemic load, and fiber and whole-grain intakes during puberty to the concurrent development of percent body fat and body mass index. American Journal of Epidemiologi, 169(6), 667-77.

Davis JN, Alexander KE, Ventura EE, Toledo-Corral CM, \& Goran MI. 2009. Inverse relation between dietary fiber intake and visceral adiposity in overweight Latino youth. The American Journal of Clinical Nutrition, 90, 1160-1166.

Duvigneaud N, Wijndaele K, Matton L, Philippaerts R, Lefevre J, Thomis M, Delecluse C, \& Duqute W. 2007. Dietary factors associated with obesity indicators and level of sports participation in Flemish adults: a cross-sectional study. Nutrition Journal, 6, 26.

Elliot SA, Truby H, Lee A, Harper C, Abbott RA, \& Davies SW. 2011. Associations of body mass index and waist circumference with: energy intake and percentage energy from macronutrients, in a cohort of Australian children. Nutrition Journal, 10, 58.

Gibson R. 2005. Principles of Nutrition Assessment. Second Edition. Oxford University, New York.

Halkjær J, Tjønnelad A,Thomsen BL, Overvad K, \& Sørensen TIA. 2006. Intake of macronutrients as predictors of 5-y changes in waist circumference. The American Journal of Clinical Nutrition, 84, 789-797.

Hu FB, Stampfer MJ, Rimm E, Ascherio A, Rosner BA, Spiegelman D, \& Willet WC. 2010. Dietary fat and coronary heart disease: a comparison of approaches for adjusting for total energy intake and modeling repeated dietary measurements. American Journal of Epidemiology, 149, 531-540.

Ighosotu S \& Tonukari NJ. 2010. The influence of dietary intake on the serum lipid profile, body mass index and risk of cardiovascular diseases in adults on the Niger Delta region. International Journal of Nutrition and Metabolism, 2(3), 40-44.

Janssen I, Katzmaryzk PT, \& Ross R. 2004. Waist circumference and not body mass index explains obesityrelated health risk. The American Journal of Clinical Nutrition, 79, 379-384.

Kusharto CM. 2006. Serat makanan dan peranannya bagi kesehatan. Jurnal Gizi dan Pangan, 1(2), 47.

Ledikwe JH, Blanck HM, Khan LK, Serdula MK, Seymour JD, Tohill BC, \& Rolls BJ. 2006. Dietary energy density is associated with energy intake and weight status in US adults. The American Journal of Clinical Nutrition, 83, 1362-1368.

Lee RD, Nieman DC. 2010. Nutritional Assessment. 5th ed. McGraw-Hill, Boston (US).

Liu S, Willet WC, Manson JE, Hu FB, Rosner B, \& Colditz G. 2003. Relation between changes in intakes of dietary fiber and grain products and changes in weight and development of obesity among middle-aged women. The American Journal of Clinical Nutrition, 78, 920-927.

Maruf FA, Akosile CO, \& Umunnah JO. 2012. Physical activity, dietary intake and anthropometric indices of a group of nigerian university undergraduates. African Journal of Physiotherapy and Rehabilitation Sciences, 4(1), 8-12.

Merchant AT, Anand SS, Kelemen LE, Vuksan V, Jacobs R, Davis B, Teo K, \& Yusuf S. 2007. Carbohydrate intake and $\mathrm{HDL}$ in a multiethnic population. The American Journal of Clinical Nutrition, 85, 225-230.

Newby PK, Peterson KE, Berkey CS, Leppert J, Willett WC, \& Colditz GA. 2003. Dietary composition and weight change among low-income 
preschool children. Archives of Pediatrics and Adolescent Medicine,157(8), 759-64.

Romaguera D, Angquist L, Du H, Jakobsen MU, Forouhi NG, Halkjær J, Feskens EJM, Van Der A DL, Masala G, \& Steffen A et al. 2011. Food composition of the diet in relation to changes in waist circumference adjusted for body mass index. PLoS ONE. 6(8): e23384. doi:10.1371/ journal.pone.0023384.

Osuji CU, Nzerem BA, Meludu S, Dioka CE, Nwobodo $\mathrm{E}$, \& Amilo GI. 2010. The prevalence of overweight/obesity and dyslipidemia amongst a group of women attending "August" meeting. Nigerian Medical Journal, 51(4), 155-159.

Sartika RAD. 2011. Faktor risiko obesitas pada anak 5-15 tahun di Indonesia. Jurnal Makara Kesehatan, 15(1), 37-43.

Schröder H, Marrugat J, Elosua R, \& Covas MI. 2003. Relationship between body mass index, serum cholesterol, leisure-time physical activity, and diet in a Mediterranean Southern-Europe population. British Journal of Nutrition, 90, 431-439.
Setiono LY. 2012. Dislipidemia pada obesitas dan tidak obesitas di RSUP Dr. Kariadi dan laboratorium klinik swasta di Kota Semarang. Media Medika Muda, 1(1).

Singh AK, Singh SK, Singh N, Agrawal N, \& Gopal K. 2011. Obesity and dyslipidemia. International Journal of Biological and Medical Research, 2(3), 824-828.

Supariasa IDN, Bakri B, \& Fajar I. 2001. Penilaian Status Gizi. EGC, Jakarta.

Suwimol S, Pimpanit L, Aporn M, Pichita S, Ratiyaporn S, \& Wiroj J. 2012. Impact of fruit and vegetables on oxidative status and lipid profiles in healthy individuals. Food and Public Health, 2(4), 113-118.

Van De Vijver LPL, Van Den Bosch LMC, Van Den Brandt PA, \& Goldbohm RA. 2009. Wholegrain consumption, dietary fibre intake and body mass index in the Netherlands cohort study. European Journal of Clinical Nutrition, 61, 31-38.

[WHO] World Health Organization. 2008. Waist Circumference and Waist-Hip Ratio: Report of a WHO Expert Consultation. WHO, Genewa. 